\title{
Correction To: Enzyme-Ligand Interaction Monitored by Synchrotron Radiation Circular Dichroism
}

Correction to:

Chapter 6 in: Nikolaos E. Labrou (ed.), Targeting Enzymes for Pharmacentical vol. 2089, https://doi.org/10.1007/978-1-0716-0163-1_6

The original version of the chapter "Enzyme-Ligand Interaction Monitored by Synchro- 9 tron Radiation Circular Dichroism" was previously published non-open access. It has now 10 been changed to open access under a CC BY 4.0 license and the copyright holder has been 11 updated to 'The Author(s).' The book has also been updated with the change.

The updated online version of this chapter can be found at https://doi.org/10.1007/978-1-0716-0163-1_6 